\title{
CULTURAL DIFFERENCES AS A KEY DETERMINANT OF TOURIST LOYALTY PERCEPTION
}

\author{
[Kulturní rozdíly jako klíčový determinant vnímání loajality turistů]
}

\author{
Andrea Králiková ${ }^{1}$, Kateřina Ryglová ${ }^{2}$ \\ ${ }^{1}$ Mendel University in Brno, Faculty of Business and Economics, Zemědèlská 1665/1, 61300 Brno \\ Email: andrea.kralikova@mendelu.cz \\ ${ }^{2}$ Mendel University in Brno, Faculty of Business and Economics, Zemédělská 1665/1, 61300 Brno \\ Email: katerina.ryglova@mendelu.cz
}

\begin{abstract}
As a result of the current COVID-19 situation, tourist loyalty is a crucial predominator in maintaining the position in the global tourism market. Nevertheless, a number of factors play a significant role in shaping tourists' loyalty, however, only a few studies focus on the tourists' cultural differences. Therefore, this paper examines their impact on the tourist loyalty perception in the Czech Republic context among American, Russian, and Finnish tourists. For the American and Finnish respondents, cultural monuments played the biggest role. Contrarily, food quality and safety were the most important factors for the Russian respondents. However, regardless of nationality, there are four high-priority factors: cultural and natural attractions, safety, and acceptance by the locals. Closer attention should be paid to safety and acceptance by the locals, as they can be altered by the government to some extent. Therefore, this study might help to provide a deeper understanding of visitor loyalty.
\end{abstract}

Keywords: cultural differences, destination image, loyalty, the Czech Republic.

JEL classification: M10, Z32

Received: 30.3.2021; Reviewed: 12.4.2021; 27.4.2021; Accepted: 3.11.2021

\section{Introduction}

Nowadays, tourist loyalty is more pronounced than ever. As a result of the global pandemic, the number of tourists decreased not only at the international but also domestic level. According to UNWTO (2020), there was a 70\% decline in international arrivals for the first eight months of 2020. Moreover, UNWTO (2020) foresees a rebound of international tourism, mainly in the third quarter of 2021. On a domestic level, according to CzechTourism (2020a), there was almost a $35 \%$ decrease in consumption connected to tourism in 2020. A moderately smaller decrease in tourism consumption is also estimated for the year 2021 (CzechTourism 2020a). Therefore, the destinations and service providers, who can maintain their loyal customers, have a substantial competitive advantage when compared to other destinations and service providers (Yoon and Uysal 2005). In addition, the marketing costs of attracting loyal customers are much lower than the marketing costs that need to be devoted to attracting new customers (Alegre and Juaneda 2006, Zhang et al. 2014). Those savings can be then used to secure the required health and safety protocols, enabling potential visitors to feel safe enough in their decision to visit that destination.

Unfortunately, loyalty is a particularly broad and complex term. Hultman et al. (2015) defined destination loyalty as a degree of the visitors' devotion to the specific destination. However, there are a significant number of factors that have an impact on tourist loyalty. Most researched factors in this field are satisfaction (Yuksel et al. 2010), uniqueness of the destination (Usakli and Baloglu 2011), tourists' motivation (Yoon and Uysal 2005), destination safety (Som et al. 2011), the value provided by the destination to their visitors (Petrick et al. 2001), previous experiences (Chi 2012), as well as the image of the destination (Bigné et al. 2001). 
There are also a few studies that focus more on the impact of visitors' personality traits regarding their loyalty to a destination. For instance, Skogland and Siguaw (2004) found that demographic factors, such as gender, age, or even education, have a significant influence on loyalty. Furthermore, Chen and Gursoy (2001) found that cultural differences influence tourist loyalty towards a specific destination. Chen and Tsai (2007) also claim that individual cultural backgrounds might lead to a different perception of various tourism services in a given destination.

Nevertheless, there are only a few studies that compare the perception of a given destination based on cultural and geographical differences (e.g., Bonn et al. 2005, Pantouvakis 2013, Andersen et al. 2017, Kim and Malek 2017). Besides, only a small number of those studies focus on European countries. Furthermore, no study deals with the loyalty perception of the Czech Republic or any of the central European countries, based on the various tourist nationalities. For this reason, the results of this paper may be used as a baseline with regard to cultural differences and loyalty perception for other central European countries as well as countries with a similar tourism structure as the Czech Republic. Additionally, Russian, and American tourists make up important source markets for other countries as well. Thus, the knowledge of the differences in loyalty perception could prove quite beneficial for those countries.

\section{Literature review}

In general, there are two main reasons why people travel: to escape from their daily routine and to experience something new (Gursoy et al. 2014). In the second case, the revisit intention of tourists will not be particularly strong. On the other hand, these types of visitors are more likely to recommend that particular destination. On that account, loyal tourists are a necessity for any given destination, no matter what the purpose of their visit. According to Chi and Qu (2008), referrals account for about $60 \%$ of sales to new customers. Consequently, destination loyalty has become a key feature for successful destination development (Prayag and Ryan 2011).

Thus, destination loyalty can be viewed as tourists' commitment towards a certain destination (Chi and Qu 2008). Moreover, according to Kao et al. (2008), destination loyalty represents one's willingness to make an investment or sacrifice to enrich the relationship with a given destination or product. Hence, destination loyalty is not only crucial for successful destination development, but it is also inevitable for ensuring success in the highly competitive tourism industry (Yoon and Uysal 2005).

Not only do loyal visitors help a destination by possibly spreading positive recommendations and revisiting the destination, but they also tend to spend more time at the destination, while also consuming more products and services at the destination (Kotler 2007, Zhang et al. 2014). Moreover, Zhang et al. (2014) add that the marketing costs for attracting loyal visitors are much lower than for first-time visitors. Rowley (2005) also adds increased organizational profitability as one of the benefits of destination loyalty.

In previous studies, authors looked at destination loyalty from three different perspectives: behavioral, attitudinal, and composite loyalty (Mechinda, Serirat and Gulid 2009, Zhang et al. 2014). Behavioral loyalty deals with visitors' behavioral outcomes. Those outcomes might, for instance, be their actual consumption of products and services, or their visit to the destination itself (Ragb et al. 2020). On the other hand, attitudinal loyalty refers to visitors' psychological motivations, such as their revisit intention or the aspiration to further recommend the 
destination. Lastly, composite loyalty is the combination of the two previously mentioned loyalties (Ragb et al. 2020).

However, most loyalty studies use two main loyalty indicators, the visitors' intention to revisit the given destination and the intention to recommend the destination to others (Opermann 2000). Especially in the tourism industry, positive referrals and WOM (Word-of-Mouth) are increasingly important. That is because they are considered as one of the most reliable and vastly used sources of information regarding any specific destination (Yoon and Uysal 2005). These positive recommendations are even more crucial for first-time visitors, as they rely more on referrals from their family and friends as well as professionals in the tourism industry (Li et al. 2008). Nowadays, those referrals and recommendations are mostly done in the online sphere via various social media, destination websites or travel forums (e.g., TripAdvisor) (Xiang and Gretzel 2010, Fotis et al. 2012). Therefore, Zhang et al. (2014) distinguish between online and face-to-face recommendations.

As a result of various advantages emerging from loyalty, there are a number of studies that deal with the factors influencing tourists' revisit intentions (Prayag and Ryan 2011, Wang and Hsu 2010, Wu 2016). The key factor that is capable of forming deeper tourists' loyalty is their satisfaction with the given destination. Those who are satisfied are more likely to revisit the destination some-time in the future, as well as are more willing to recommend it to their friends and family (Kozak and Remington 2000, Tian-Cole and Cromption 2003), or leave a positive comment or recommendation on social media (Bala Bakni et al. 2014). Moreover, satisfaction can have an influence on destination choice as well as on product and service consumption (Chi 2012).

On the other hand, according to Carroll and Ahuvia (2006), as well as Chen and Phou (2013), focusing solely on tourist satisfaction is no longer sufficient. As a result of the strong competition among tourist destinations, satisfaction might not always lead to tourists' loyalty. More specifically, even if the tourists are satisfied with their stay at the destination, they might not come back in the future (Bigné et al. 2001, Petrick et al. 2001), as they would like to experience something new. Therefore, closely examining the factors that might influence both the tourists' satisfaction as well as their loyalty is inevitable.

As claimed by authors such as Lee et al. (2005) and Chen and Tsai (2007), the factor that might do just that is the destination image. According to Lee et al. (2005), having a positive perception of the destination image in the tourists' minds will lead to a positive perception of the entire experience at the destination. This might then result in higher tourist' satisfaction, and consequently in their loyalty towards the destination. Therefore, communicating a positive destination image has become one of the priorities for destination management and marketing (Molina et al. 2010). The knowledge of how the visitors perceived the destination image might lead to a better understanding of the competitiveness of the destination as well as to the better positioning of the destination (Prayag 2008).

The destination image and its formation are influenced by various factors, namely one's knowledge of the destination (Jensen et al. 2015), one's previous visit to the destination (Tasci et al. 2007), as well as one's experiences with various activities at the destination (Beerli and Martin 2004). Moreover, the destination image continues to be formed even after one visits a particular destination. Therefore, appealing to the visitors during their experience with the destination is also inevitable. 
With that being said, the destinations with a more positive image have a larger chance that they get to the tourists' final decision process of choosing which destination to visit (Chi and $\mathrm{Qu}$ 2008). The positive image of a destination can also influence tourist behavior (Jenkins 1999) and the activities selected at the destination (Sun et al. 2013).

Satisfaction can also be perceived as the visitors' emotional reaction to the product or service that has met their expectations and needs (Zeithaml and Bitner 2003, Schneider and White, 2004). Since the visitors' emotions are hugely influenced by their demographic and psychological factors, paying closer attention to them is therefore inevitable. Accordingly, Chen and Tsai (2007) discovered that cultural values influence not only the perception of a destination's image but also the tourists' behavior. On that account, each tourist's culture might lead to different perceptions of the same destination. Moreover, other studies focus on psychological factors, such as cultural values. For instance, Lopes (2011) found that cultural values have a substantial impact on destination image perception as well as the creation of the destination image. According to Beerli and Martin (2004), not only cultural values but also other psychological factors, such as the tourists' motivation and lifestyle, have a huge influence on the formation of a destination's image.

On top of that, every culture has its specific characteristics, such as religion, history, language, cultural norms, and ideas as well as their political and social structures. Therefore, the country of origin can influence the values, attitudes, and behaviors of individual visitors (Govers et al. 2007). Besides culture, other socio-demographic factors, such as the gender, age, and education of visitors have a substantial influence on their loyalty towards any particular tourist destination (Skogland and Siguaw 2004). Moreover, according to Štumpf et al. (2020) tourist's motivation, age, travel distance, as well as country of origin determine the intention to revisit more notably than the satisfaction attributes. Culture as well as the demographic characteristics and the personalities of the travelers also influence the motivation to travel to specific destinations (Swarbrooke and Horner 2007).

Another factor worth mentioning is cultural distance. According to Liu et al. (2020), cultural distance can be characterized as a perceived difference between one's home and foreign country. Moreover, cultural distance can be closely associated with some country-based differences, such as language, economic disparities, political, and legal system differences, as well as geographical distance (Dow 2000, Durand et al. 2016). Some recent studies, like that of Jackman et al. (2020), show that cultural distance influences the visitors' destination choice and their behavior. Liu et al. (2020) also added that visitors from more different cultures will be more effectively influenced than locals with less cultural distance. Apart from being one of the most crucial satisfaction and loyalty factors, destination image and cultural differences are significant aspects in successful tourism development as well as in destination marketing (Hallmann et al. 2014).

Based on the literature, it can be hypothesized that image perception might differ based on visitors' geographical and cultural differences (Frias et al. 2012, Jensen et al. 2015). Therefore, the main focus of this paper lies in the investigation of whether those differences are also significant in the context of central Europe, as well as in countries that are mostly oriented on cultural and city tourism. Accordingly, the impact of cultural and geographical differences on tourist loyalty as well as the perception of the Czech Republic as a tourist destination was examined. 
Consequently, taking all the previous studies into account, as well as the current pandemic situation and the highly competitive tourism market, identifying factors that are important for the specific group of tourists is necessary (e.g., based on age, activities, or nationality). The destinations that can correctly identify these factors for their target group have a greater chance of retaining loyal visitors (McDowall, 2010). Moreover, a better understanding of these loyalty formation factors is crucial for destination survival and success (Gursoy et al. 2014).

\section{Materials and methods}

This paper aims to investigate whether the cultural and geographical differences are significant within the context of destination loyalty, for the central European countries, that are mostly oriented on cultural and city tourism. In order to do so, the perception of the Czech Republic as a tourist destination as well as the impact of various nationalities on tourist loyalty towards the Czech Republic were examined. Hence, the primary data among American, Russian, and Finnish respondents were obtained during 2017 and 2019. The data were mostly collected via online questionnaires on various Facebook and Reddit groups as well as national travel blogs among American, Finnish, and Russian inhabitants. Moreover, face-to-face structured interviews in Prague, Karlovy Vary and Brno were conducted in order to gain insights from Russian visitors. On the other hand, face-to-face structured interviews with American visitors were conducted in Portland and Corvallis (Oregon, USA). The total number of respondents with the sample structure for each country is described in Table 1. As it is evident from this table, only approximately $23 \%$ of Russian respondents are men. On that account, quota sampling based on the gender of the respondents was not possible to apply in the case of the Russian respondents.

Table 1: Sample Structure

\begin{tabular}{l|ll|ll|ll}
\hline & \multicolumn{2}{|c|}{ Russia } & \multicolumn{2}{c|}{ Finland } & \multicolumn{2}{c}{ USA } \\
\hline $\begin{array}{l}\text { Category of } \\
\text { respondents }\end{array}$ & $\begin{array}{l}\text { Absolute } \\
\text { number }\end{array}$ & $\begin{array}{l}\text { Relative } \\
\text { number (\%) }\end{array}$ & $\begin{array}{l}\text { Absolute } \\
\text { number }\end{array}$ & $\begin{array}{l}\text { Relative } \\
\text { number (\%) }\end{array}$ & $\begin{array}{l}\text { Absolute } \\
\text { number }\end{array}$ & $\begin{array}{l}\text { Relative } \\
\text { number (\%) }\end{array}$ \\
\hline Men & 127 & 23.26 & 224 & 52.96 & 44 & 54.32 \\
\hline Women & 419 & 76.74 & 199 & 47.04 & 37 & 45.68 \\
\hline Total & 546 & 100 & 423 & 100 & 81 & 100 \\
\hline
\end{tabular}

Source: Own processing

Considering the fact that this study is aimed at the comparison of perceived loyalty to the Czech Republic, going forward, only respondents who visited the Czech Republic were taken into consideration.

Overall, almost $43 \%$ of the Finnish respondents were employed and approximately $44 \%$ were students. That also represents the age structure of the Finnish respondents, where almost $86 \%$ fit into the age group between 18 and 39 years old. On the other hand, almost $52 \%$ of the Americans were employed and another $21 \%$ were retired. That also represents the age structure, where almost $35 \%$ of the American respondents fall under the age group of 51 and older. If we look at the Russian respondents, approximately $50 \%$ have their family monthly income within the range of 20 to 60 thousand rubles (approximately 225 to 670 EUR). Furthermore, around $48 \%$ of the Russian respondents lived in a city with more than 1 million inhabitants. Those above-mentioned visitors' characteristics did not meet the quota requirement. Therefore, we are not showing them in one summary table.

On top of that, the survey alone encompassed various questions related to destination image and loyalty as well as questions regarding respondents' stay in the Czech Republic, their travel behavior, and questions that measure their demographic information, such as gender, age, income, or economic activity. The questions regarding the image factors were formulated on a 
Likert scale, with answers to the given statements ranging from 'strongly disagree' to 'strongly agree'. Those image factors were formulated with regard to previous studies (Kim and Richardon 2003, Breelie and Martin 2004, Prayag 2007, Nunkoo 2013, Ryglová et al. 2018, Králiková et al. 2020).

The visitors' loyalty towards the Czech Republic was reflected by the two loyalty indicators (Chen and Tsai 2007), willingness to recommend and revisit the Czech Republic. Furthermore, a multiple regression analysis performed on a 5\% significance level and executed according to the OLS (Ordinary Least Square) method, was used to evaluate the impact of particular image factors (e.g., cultural and natural attractions, safety or acceptance by the locals) on loyalty indicators.

In some cases, the dependence of image factors on the respondents' characteristics was evaluated (e.g., the dependence of image factors on respondents' gender, or the dependence of the overall image of a destination in the tourists' revisit intention, depending on the age of the respondents). Given the non-normality and ordinality of data, the Kruskal-Wallis test was used (Sheskin 2011).

\section{Results}

To compare the perception of loyalty towards the Czech Republic among the selected nationalities, we need to take a closer look at the respondents, among other factors, in relation to their travel specifics caused by nationality.

\subsection{Russia}

In 2019, there were more than 564 thousand Russian tourists who visited the Czech Republic, which accounts for the sixth source country for the Czech Republic (CSO 2020a). According to the Czech Statistical Office (2020b), Russian tourists accounted for $5.2 \%$ of all non-resident tourists in the Czech Republic in 2019.

From the perspective of the Czech Republic, the age of most Russian tourists falls between 30 and 59 and they come either from Moscow, Saint Petersburg, or Yekaterinburg. They mainly travel with their partners, usually without kids (Country Report Russia 2020). This is also evident from our research, where almost $32 \%$ of the Russian respondents visited the Czech Republic with their family. On the other hand, in our case, they mostly traveled alone (more than $34 \%)$. Traveling with friends was also quite common (28\%).

Their main reason for visiting the Czech Republic is recreation, and they are especially interested in cultural and natural attractions (Country Report Russia 2020). If we look at the result of this research, their purpose of visit corresponds with the Country Report on Russia (2020). More than $59 \%$ of respondents visited the Czech Republic for leisure purposes since the spa and city tourism are highly preferred among this clientele. Furthermore, $51 \%$ of the Russian respondents wanted to visit something new. Therefore, communicating the other interesting places that the Czech Republic can offer to Russian visitors to spark their interest for their next visit is inevitable.

It is also worth mentioning that right after Slovakian students, Russians are the second-largest group of international university students studying in the Czech Republic. According to the Ministry of Education, Youth and Sports (2020), 6,221 Russian students studied in the Czech Republic in 2019. Therefore, 'studying' as the purpose for their visit is larger than in the other 
two compared countries (there were only 49 Finnish and 387 American university students in 2019).

Table 2: Purpose of the Visit

\begin{tabular}{l|lc|lc|cc}
\hline & \multicolumn{2}{|c|}{ Russia } & \multicolumn{2}{c|}{ Finland } & \multicolumn{2}{c}{ USA } \\
\hline & $\begin{array}{c}\text { Purpose of the } \\
\text { visit }\end{array}$ & $\begin{array}{c}\text { Relative } \\
\text { number (\%) }\end{array}$ & $\begin{array}{c}\text { Purpose of the } \\
\text { visit }\end{array}$ & $\begin{array}{c}\text { Relative } \\
\text { number (\%) }\end{array}$ & $\begin{array}{c}\text { Purpose of the } \\
\text { visit }\end{array}$ & $\begin{array}{c}\text { Relative } \\
\text { number (\%) }\end{array}$ \\
\hline $\mathbf{1 .}$ & Leisure & 59.16 & Leisure & 75.41 & Round trip & 25.93 \\
\hline $\mathbf{2 .}$ & $\begin{array}{l}\text { Visiting } \\
\text { something new }\end{array}$ & 51.28 & Friends and family & 6.15 & $\begin{array}{l}\text { Culture and } \\
\text { exploring }\end{array}$ & 24.69 \\
\hline $\mathbf{3 .}$ & Study & 31.87 & Business & 5.67 & Friends and family & 19.75 \\
\hline
\end{tabular}

Source: Own processing

Regarding the loyalty of Russian tourists, it is inevitable to know that recommendations from friends and family, as well as comments on social media, are crucial information sources for Russian tourists during their destination choice process (Country Report Russia 2020).

Based on our research, the Russian tourists were happy that they chose the Czech Republic as their holiday destination. They are also particularly loyal and are willing to revisit the Czech Republic some-time in the future, as well as recommend the Czech Republic to their friends and family.

\subsection{USA}

Many Americans prefer holidays overseas, where almost $25 \%$ of those Americans visit Europe repeatedly. While traveling, safety is the most important issue for them, followed by reasonable prices, accommodation, and destination attractivity (Country Report USA 2020).

In 2019, there were more than 584 thousand American tourists that visited the Czech Republic, which represents the fifth source country for the Czech Republic (CSO 2020a) and it accounts for $5.4 \%$ of all non-resident tourists in the Czech Republic for that year (CSO 2020b).

Most American tourists belong to the age group of 30 to 39 years old, closely followed by the age group of 60 years and older. More than $75 \%$ of those tourists visited the Czech Republic for the first time. The sources of information for American tourists are mostly recommendations from their friends and family, along with the internet and information received from travel agencies. Moreover, Americans mostly visit the Czech Republic for recreational purposes. Therefore, they mostly like to visit various cultural monuments throughout the country. On the other hand, they are also quite interested in gastronomy, various social events, as well as natural attractions (Country Report USA 2020).

The results of this paper also support the Country Report on the USA (2020), where culture and exploring was the second-largest purpose of the visit for the American respondents (see Table 2). Moreover, almost $26 \%$ of respondents visited the Czech Republic as one of the destinations on their round trip across Europe. This was also the main reason for their visit according to the Country Report USA (2020). This might be the result of the large distance between the US and the Czech Republic, as well as the moderately short length of stay (on average they stay in the Czech Republic for 3.48 days and more than $65 \%$ of American tourists visit the Czech Republic for a maximum of seven days). Nevertheless, almost $20 \%$ of the American respondents visited their friends and family in the Czech Republic.

Similarly, to the study regarding the American market for the year 2017, processed by the Ipsos agency (CzechTourism 2018), the Czech Republic was also in this research mostly associated 
with the capital, Prague, followed by beer and architecture. A relatively high number of respondents also mentioned Charles Bridge and other Prague cultural monuments. Prague cultural monuments were also the most unique tourist attraction for the American respondents. According to the Country Report on the USA (2020), those tourists who visited the Czech Republic are usually quite satisfied and are willing to recommend the Czech Republic to their friends and family. Moreover, when making travel decisions, referrals and WOM play a large role for Americans. Overall, we also found that American women are more loyal to the Czech Republic than men, meaning they are more willing to recommend and revisit the Czech Republic than men. In addition, the American women and the respondents within the age group of 51 to 60 years old were more satisfied.

\subsection{Finland}

In 2019, there were more than 72 thousand Finnish tourists who visited the Czech Republic, which represents $0.7 \%$ of all non-resident tourists in the Czech Republic for that year (CSO 2020b).

Most of the Finnish tourists visited the Czech Republic for the first time and stated their purpose to be recreational (CzechTourism 2020c). This is also in line with this research, where more than $75 \%$ of the Finnish respondents visited the Czech Republic for leisure purposes, which is similar to the Russian respondents. In both cases, this accounts for more than half of the respondents. A smaller number of respondents (around $6 \%$ ) visited the Czech Republic for business purposes and to visit their friends and family (see Table 2).

According to Messukeskus (2018), $55 \%$ of Finnish travels are outside of Finland, where Europe is the leading destination. Moreover, there is an increasing trend in the popularity of eastern and western European destinations among the Finnish people. This is in line with the results of our study, where more than $50 \%$ of the Finnish respondents traveled to Europe for their holiday. Moreover, about $41 \%$ of the respondents consider the Czech Republic suitable for the summer holiday. On the contrary, only $0.7 \%$ of the Finnish respondents considered the Czech Republic suitable for their winter holiday. Overall, approximately $90 \%$ of the Finnish respondents considered the Czech Republic a city-type destination, more than $77 \%$ a beer-type destination, and almost $66 \%$ a cultural-type destination.

Same as with the Russian and American tourists, Finns visited the Czech Republic mostly with their partner. Furthermore, the Finnish tourists were generally quite satisfied in the Czech Republic (CzechTourism 2020c).

Generally, we found that the Finnish respondents are decidedly loyal to the Czech Republic. Only a little more than $2 \%$ of respondents would not recommend the Czech Republic to their friends and family as well as not come back again.

\subsection{The Czech Republic loyalty perception}

Overall, American and Finnish men evaluated the image factors higher than women. This, however, is not true for the Russian respondents, where, on average, the women evaluated the factors higher than men. However, that might be caused by the fact that only $23.3 \%$ of the Russian respondents were men.

Regardless of the respondents' gender, cultural monuments were the highest evaluated image factors for the American respondents, followed by the offer of restaurants and cafes, as well as safety and natural attractions. Similarly, for Finnish respondents, the highest-ranking factor was 
cultural monuments, more specifically, the picturesque historical cities and the bridge over the Vltava river (Charles Bridge). They also ranked the perception of the Czech Republic as a beeroriented country very high. Beer was also the second most common characteristic of the Czech Republic (after Prague) for Americans.

We can see a different ranking of factors among the Russian respondents, where the most relevant were the price category factors, followed by the transport and accommodation category factors. On the other hand, if we look at the specific factors, food quality and freshness was the most important factor for the Russian respondents, along with the safety of accommodation as well as the reasonable prices of food. Therefore, it is safe to say that the Russian respondents are more price sensitive when compared to other nationalities.

Apart from the most important factors for each nationality, other factors play a significant role in loyalty perception as well. Regardless of the respondents' nationality, four image factors are quite significant. The most important factor was, previously mentioned, cultural attractions. Even though it was not the most significant image factor for the Russian tourists, the ranking of this factor is still particularly high. As can be seen in the table below, more than $90 \%$ of the American and Finnish respondents either agree or strongly agree with the statement that the Czech Republic is attractive for tourists in terms of cultural attractions. In the case of the Russian respondents, the percentage is slightly lower $(80 \%)$.

Table 3: Attractiveness of the Czech Republic - Cultural Attractions

\begin{tabular}{l|cc|cc|cc}
\hline & \multicolumn{2}{|c|}{ Russia } & \multicolumn{2}{c|}{ Finland } & \multicolumn{2}{c}{ USA } \\
\hline & $\begin{array}{c}\text { Absolute } \\
\text { number }\end{array}$ & $\begin{array}{c}\text { Relative } \\
\text { number (\%) }\end{array}$ & $\begin{array}{c}\text { Absolute } \\
\text { number }\end{array}$ & $\begin{array}{c}\text { Relative } \\
\text { number (\%) }\end{array}$ & $\begin{array}{c}\text { Absolute } \\
\text { number }\end{array}$ & $\begin{array}{c}\text { Relative } \\
\text { number (\%) }\end{array}$ \\
\hline Agree & 95 & 17.40 & 168 & 37.20 & 28 & 34.60 \\
\hline Strongly agree & 333 & 60.99 & 249 & 55.10 & 50 & 61.70 \\
\hline Total & 428 & 78.39 & 417 & 92.30 & 78 & 96.30 \\
\hline
\end{tabular}

Source: Own processing

A different situation can be seen with the factor of natural attractions. For the American and Russian respondents, this is one of the most significant image factors. However, for the Finnish respondents, this factor is slightly less important. Other key factors are safety and acceptance by the locals. These two factors were ranked the same by American, Finnish as well as Russian respondents.

Maintaining this perception of a safe country is now even more crucial than before. Therefore, preserving the perception of a safe country with regard to COVID-19 should be one of the main priorities of any DMOs in the Czech Republic. Hence, the advantage of the Czech Republic is its general perception as a safe country. If we look at the Global Peace Index from 2016 to 2019, the Czech Republic was ranked 7th out of 163 countries worldwide. In 2020, the ranking slightly decreased, and the Czech Republic has since gone down to 8th. Moreover, most indicators that form the Global Peace Index are expected to deteriorate (except the military expenditures, as the countries redirect their resources to help with the current economic issues) (visionofhumanity.org 2020).

Since the United States are the most important source country for the Czech Republic, out of the analyzed ones, we have also conducted regression analyses for the American visitors. The results can be seen in the tables below. 
Table 4: Regression Analysis - Intention to Revisit

\begin{tabular}{lcc}
\hline Intention to revisit & Reg. coef. & P-value \\
\hline Constant & 0.192 & 0.828 \\
\hline Acceptance by the locals & 0.379 & 0.010 \\
\hline Staff quality & 0.295 & 0.022 \\
\hline Price & 0.236 & 0.094 \\
\hline Source: Own processing; $\mathrm{R}^{2}=0.173 ; \mathrm{R}^{2}$ adj. $=0.139,10 \%$ significance level
\end{tabular}

Table 5: Regression Analysis - Recommendation

\begin{tabular}{lcc}
\hline Recommendation & Reg. coef. & P-value \\
\hline Constant & 0.932 & 0.207 \\
\hline Price & 0.292 & 0.014 \\
\hline Acceptance by the locals & 0.240 & 0.049 \\
\hline Staff quality & 0.225 & 0.036
\end{tabular}

Source: Own processing; $\mathrm{R}^{2}=0.176 ; \mathrm{R}^{2}$ adj. $=0.142,10 \%$ significance level

Generally, three factors have an influence on the American respondents' loyalty to the Czech Republic. These factors are the acceptance by the locals, staff quality, and price. Paying more attention to these factors when considering the loyalty of American visitors is thus inevitable.

As it is evident from Table 6, Russians are the most loyal towards the Czech Republic among research nationalities. Furthermore, the intention to recommend the Czech Republic is stronger than the revisit intention. This is especially true for Finnish respondents, where more than 97 $\%$ would recommend visiting the Czech Republic to their friends and family. On the other hand, only $74 \%$ of Finnish respondents would revisit the Czech Republic some time in future. The least loyal are American respondents. That might be caused by the great distance between the Czech Republic and the US. Hence, the revisit intention is lowest among other researched nationalities. On the other hand, almost $75 \%$ of the American respondents were satisfied or very satisfied, which is a very positive sign for Czech destinations and the service providers. Therefore, the distance between the home and visiting country should be the topic for future research.

Table 6: Loyalty indicators

\begin{tabular}{l|c|c|c}
\hline & Russia (\%) & Finland (\%) & USA (\%) \\
\hline Revisit intention & 89.23 & 74.00 & 56.79 \\
\hline Intention to recommend & 90.00 & 97.40 & 62.96 \\
\hline Source: Own processing
\end{tabular}

\section{Discussion}

According to Pantouvakis (2013), some nationalities will value infrastructure more, while others are more interested in people-related services. This is also evident from the results of our paper, where Russians are more people-oriented compared to the Americans and Finns. On the other hand, Americans evaluate cultural as well as natural attractions and various social events higher than the other researched nationalities. Moreover, our findings indicate that the American respondents were the most satisfied with their stay in the Czech Republic when compared to other nationalities. Pantouvakis (2013) came to the same conclusion. In his study Belgian and American visitors presented the highest satisfaction and loyalty scores among the 10 examined nationalities.

While there are differences in image and loyalty perception based on the cultural differences, some authors, such as Jensen et al. (2015) and Andersen et al. (2017), found that there are some factors that the respondents evaluate the same, regardless of their nationality. Jensen et al. (2015) found that reindeers and the northern lights are the two factors that the respondents most 
often associated with northern Norway, no matter their nationality. In the same manner, the mix of family-friendly cross country and alpine skiing relate well to the destination images held by all the researched nationalities (Denmark, Sweden, and Germany) in Andersen et al. (2017) study of the Lillehammer region (Norway).

If we look at the results of our study, there are four factors that are quite important, regardless of the respondents' nationality. We can see that apart from cultural monuments and natural attractions, which are predetermined and cannot be changed directly, there are two factors: safety and acceptance by the locals, which can be altered to some extent by the government or municipalities in particular destinations. This is particularly fundamental in terms of the two main perspectives: overtourism and COVID-19. Just to be clear, the factor safety does not include only security in relation to terrorist attacks, theft, or safety in terms of COVID-19. This factor also encompasses security related to other diseases (e.g., malaria or hepatitis) or drinking water.

As is evident from our research, most foreign tourists visit the capital city of Prague. Moreover, many of those tourists stay only in Prague. In 2019 there were more than 8 million tourists who visited Prague (CSO 2020b). The problem is that they usually visit the same monuments and attractions located on the so-called "Royal Route", which starts in Old Town, crosses Charles Bridge, and ends at Prague Castle. Therefore, these large crowds of people become a burden for local people living near those main tourist attractions. This is why the city government appointed a "night mayor", whose role is to ensure that residents living in this area around the various pubs and clubs are not disturbed (The Guardian 2019).

On that account, paying closer attention to the locals and ensuring that they feel welcome in their own city, as it is essential for tourists too, is inevitable. As the results of this paper show, acceptance by the locals is an important loyalty factor. When the tourists feel welcome, they may decide to visit the Czech Republic again. That may also have a positive effect on overtourism, especially in Prague, as the repeat visitors will not only stick to the "Royal Route". As a consequence, they might also visit other parts of Prague or even visit other destinations outside Prague.

That has also been the case for Prague, where Prague City Tourism began promoting other attractions in neighboring areas of the city center. They even published brochures called Prague Walks that promote these attractions (Prague City Tourism 2021). Furthermore, due to the COVID-19 pandemic, there has been an enormous decline in foreign visitors in Prague. Therefore, the city government started to take action to deal with the overtourism and be more prepared for the tourists when the pandemic situation will be at ease. The city has, for instance, closed fraudulent exchange offices and other tourist traps (Deutsche Welle 2020).

If we look closely at the global pandemic side, most countries tried (during the summertime) to attract as many domestic tourists as possible in the effort to mitigate their losses tied to a lack of foreign visitors. Therefore, as soon as the pandemic begins to decline and tourism picks back up, the perception of any country as a safe country to travel to will be quite crucial. The same goes for acceptance by the locals. When the locals will not feel safe because of the foreign tourists who they think may spread the virus, these locals can begin to feel negatively towards the tourists. In turn, the tourists might then feel as if they are not welcome, and it is possible that they might not feel satisfied in the given destination or might not even choose to visit that destination in the first place. Presenting the country or destination as safe and suitable for 
traveling, as well as presenting the traveling of foreign tourists as safe for locals, is therefore inevitable.

\section{Conclusion}

The innovativeness of this study lies in the analysis of the perception of the Czech Republic in the context of the destination image and loyalty based on the various tourists' nationalities. No such study has ever been performed in the Czech Republic or any other central European countries. Therefore, the results can serve as a baseline regarding the cultural differences and loyalty perception in the context of central Europe, as well as for other countries that are focusing on cultural and city tourism. Furthermore, the results of this paper could be used by various service providers and destination managers in their marketing strategies that are aimed at different visitors' nationalities.

Apart from the four image factors (cultural and natural attractions, as well as safety and acceptance by the locals) that are quite crucial for the American, Russian as well as Finnish respondents, there are a number of factors that the respondents perceived differently. For example, natural attractions, sustainable development, and the uniqueness of the destinations were more significant for the American respondents. In terms of their revisit intentions, Americans are also very likely to be influenced by the overall image of the destination. This is especially observable in older generations (51 years and older).

On the other hand, Russians are more price sensitive. Price factors are by far the most essential for them. They are also less likely to come back to the Czech Republic should the prices increase. That being said, the impressive architecture, as well as the cultural and natural attractions, is also quite important in their perception of the Czech Republic. They are also particularly people-oriented, and the quality of the hotel and restaurant staff is crucial for them. Lastly, the Finns are more beer-oriented than Americans and Russians. Hence, they consider the Czech Republic a beer tourism country. Furthermore, beer and nightlife were among the highest evaluated image factors. That being said, historical towns and monuments are more significant for them. On top of that, the peaceful, as well as an intriguing atmosphere of the Czech Republic had an impact on their experience.

Unfortunately, there are some limits to this paper. First of all, the data were obtained before the COVID-19 pandemic. Therefore, the perception of the Czech Republic today might slightly differ from the pre-COVID-19 era. Furthermore, the structure of respondents, as well as the data sets, is not the same for all nationalities. Consequently, we were not able to ensure the quota sampling based on the gender of the Russian respondents.

The study compares different data sets for each nationality. Therefore, future research may consider this and compare loyalty perception based on the same structure of data sets. In our study, we compared American, Russian, and Finnish tourists. It might be interesting to also conduct a similar study for Asian visitors of the Czech Republic (as this is also one of the largest source markets for the Czech Republic) and see if the perception differs significantly.

\section{Acknowledgement}

This research was supported by the project of the Internal Grant Agency of the Faculty of Business and Economics of Mendel University in Brno (PEF_DP_2021011). 


\section{References}

[1] ALEGRE, J. and C. JUANEDA, 2006. Destination loyalty: Consumers' economic behavior. Annals of tourism research, 33(3), pp.684-706. DOI: 10.1016/j.annals.2006.03.014.

[2] ANDERSEN, O., H. ØIAN, Ø. AAS and T. TANGELAND, 2018. Affective and cognitive dimensions of ski destination images. The case of Norway and the Lillehammer region. Scandinavian Journal of Hospitality and Tourism, 18(2), 113-131. DOI: 10.1080/15022250.2017.1318715.

[3] BEERLI, A. and J. D. MARTIN, 2004. Factors influencing destination image. Annals of tourism research, 31(3), 657-681. DOI: 10.1016/j.annals.2004.01.010.

[4] BEERLI, A. and J. D. MARTIN, 2004. Tourists' characteristics and the perceived image of tourist destinations: a quantitative analysis - a case study of Lanzarote, Spain. Tourism Management, 25(5), 623-636. DOI: 10.1016/j.tourman.2003.06.004.

[5] BIGNÉ, J. E., M. I. SANCHEZ and J. SANCHEZ, 2001. Tourism image, evaluation variables and after-purchase behavior: Inter-relationship. Tourism Management, 22(6), 607-616. DOI:10.1016/S0261-5177(01)00035-8.

[6] BONN, M. et al., 2005. International versus Domestic Visitors: An Examination of Destination Image Perceptions. Journal of Travel Research 43(3): 294-301. DOI: 10.1177/0047287504272033.

[7] CARROLL, B. A. and A. C. AHUVIA, 2006. Some antecedents and outcomes of brand love. Marketing letters, 17(2), 79-89.

[8] CHEN, C. and D. TSAI, 2007. How destination image and evaluative factors affect behavioral intentions? Tourism Management 28: 1115-1122. DOI: 10.1016/j.tourman.2006.07.007.

[9] CHEN, C. F. and S. PHOU, 2013. A closer look at destination: Image, personality, relationship and loyalty. Tourism management, 36, 269-278. DOI: 10.1016/j.tourman.2012.11.015.

[10] CHEN, J. S. and D. GURSOY, 2001. An investigation of tourists' destination loyalty and preferences. International Journal of Contemporary Hospitality Management. DOI: $10.1108 / 09596110110381870$.

[11] CHI, C. G. Q., 2012. An examination of destination loyalty: Differences between first-time and repeat visitors. Journal of Hospitality \& Tourism Research, 36(1), 3-24. DOI: $10.1177 / 1096348010382235$.

[12] CSO Český statistický úr̆ad, 2020a. Satelitní účet cestovního ruchu (Tourism satellite account) [online]. [cit. 2021-01-07]. Available at: https://www.czso.cz/csu/czso/satelitni_ucet_cestovniho_ruchu.

[13] CSO Český statistický úřad, 2020b. Statistická ročenka České republiky 2020 (Statistical Yearbook of the Czech Republic 2020). ISBN 978-80-250-3051-6.

[14] CZECHTOURISM, 2018a. Průzkum vnímání značky Česká republika v zahraniči (A survey of the Czech Republic brand perception abroad) [online]. [cit. 2019-03-28]. Available at: https://www.czechtourism.cz/institut-turismu/marketingovyvyzkum/analyzy/pruzkum-vnimani-znacky-ceska-re-publika-v-zahranici/.

[15] CZECHTOURISM, 2020. Country Report Russia 2019 [online]. [cit. 2021-01-07]. Available at: https://tourdata.cz/country-reporty/rusko-2019/. 
[16] CZECHTOURISM, 2020a. Dopady COVID19 2020 - 2021 (Impacts of COVID 192020 2021) [online]. [cit. 2021-01-06]. Available at: https://tourdata.cz/dopady-covid/dopadycovid19-2020-2021/.

[17] CZECHTOURISM, 2020c. Tracking domácího a přijezdového cestovního ruchu 2017 2020 (Tracking of Domestic and Inbound Tourism 2017 - 2020) [online]. [cit. 2021-0107]. Available at: https://tourdata.cz/data/tracking-domaciho-a-prijezdoveho-cestovnihoruchu/.

[18] DEUTSCHE WELLE, 2020. Overtourism in Prague: Ideas for post-coronavirus times? [online]. [cit. 2021-01-12]. Available at: https://www.dw.com/en/overtourism-in-pragueideas-for-post-coronavirus-times/a-54937352.

[19] DOW, D., 2000. A note on psychological distance and export market selection. Journal of International Marketing, 8(1), 51-64. DOI: 10.1509/jimk.8.1.51.19563.

[20] DURAND, A., E. TURKINA and M. ROBSON, 2016. Psychic distance and country image in exporter-importer relationships. Journal of International Marketing, 24(3), 3157. DOI: 10.1509/jim.15.0056.

[21] FOTIS, J. N., D. BUHALIS and N. ROSSIDES, 2012. Social media use and impact during the holiday travel planning process (pp. 13-24). Springer-Verlag.

[22] FRIAS, D. M., M. A. RODRIGUEZ, J. A. CASTANEDA, C. M. SABIOTE and D. BUHALIS, 2012. The Formation of a Tourist Destination's Image via Information Sources: the Moderating Effect of Culture. International Journal of Tourism Research, 14(5), 437-450. DOI: 10.1002/jtr.870.

[23] GENG-QING CHI, C. and H. QU, 2008. Examining the structural relationships of destination image, tourist satisfaction loyalty: An integrated approach. Tourism management, 29, 624-636. DOI: 10.1016/j.tourman.2007.06.007.

[24] GOVERS, R., F. M. GO and K. KUMAR, 2007. Virtual destination image a new measurement approach. Annals of Tourism Research, 34(4), 977-997. DOI: 10.1016/j.annals.2007.06.001.

[25] GURSOY, D., J. S. CHEN and C. G. CHI, 2014. Theoretical examination of destination loyalty formation. International Journal of Contemporary Hospitality Management, 26(5), 809-827. DOI: 10.1108/IJCHM-12-2013-0539.

[26] HALLMANN, K., S. MÜLLER and S. FEILER, 2014. Destination competitiveness of winter sport resorts in the Alps: how sport tourists perceive destinations? Current Issues in Tourism, 17(4), 327-349. DOI: 10.1080/13683500.2012.720247.

[27] HULTMAN, M., D. SKARMEAS, P. OGHAZI and H. M. BEHESHTI, 2015. Achieving tourist loyalty through destination personality, satisfaction, and identification. Journal of Business Research, 68(11), pp.2227-2231. DOI: 10.1016/j.jbusres.2015.06.002.

[28] JACKMAN, M., T. LORDE, S. NAITRAM and T. GREENAWAY, 2020. Distance matters: the impact of physical and relative distance on pleasure tourists' length of stay in Barbados. Annals of Tourism Research, 80, 102794. DOI: 10.1016/j.annals.2019.102794.

[29] JENKINS, O., 1999. Understanding and measuring tourist destination image. International Journal of Tourism Research, 1(1), 1-15. DOI: 10.1002/(SICI)15221970(199901/02)1:1<1::AID-JTR143>3.0.CO;2-L.

[30] JENSEN, Ø., J. S. CHEN and T. KORNELIUSSEN, 2015. Cultural-Geographic Influences of Destination Images: A Case of Northern Norway. Advances in Hospitality 
and Leisure. Emerald Group Publishing Limited, pp. 3-19. DOI: 10.1108/S1745354220150000011001.

[31] KAO, Y. F., L. S. HUANG and C. H. WU, 2008. Effects of theatrical elements on experiential quality and loyalty intentions for theme parks. Asia Pacific Journal of Tourism Research, 13(2), 163-174. DOI: 10.1080/10941660802048480.

[32] KIM, W. and K. MALEK, 2017. Effects of self-congruity and destination image on destination loyalty: the role of cultural differences. Anatolia: An International Journal of Tourism \& Hospitality Research. 28(1):1-13. DOI:10.1080/13032917.2016.1239209.

[33] KIM, H. and S. L. RICHARDSON, 2003. Motion picture impacts on destination images. Annals of Tourism Research. (30), 216 - 237. DOI: https://doi.org/10.1016/S01607383(02)00062-2.

[34] KOTLER, P. a K. L. KELLER, 2007. Marketing Management. 1. edition. Praha: GradaPublishing. 792 s. ISBN 978-80-247-1359-5.

[35] KOZAK, M. and M. RIMMINGTON, 2000. Tourist Satisfaction with Mallorca, Spain, as an off-season holiday destination. Journal of Travel research, 38, 260-269. DOI: $10.1177 / 004728750003800308$.

[36] KRÁLIKOVÁ, A., A. PERUTHOVÁ and K. RYGLOVÁ, 2020. Impact of destination image on satisfaction and loyalty. Acta Universitatis Agriculturae et Silviculturae Mendelianae Brunensis, 68(1), 199-209. DOI: 10.11118/actaun202068010199.

[37] LEE, C. K., Y. K. LEE and B. K. LEE, 2005. Korea's destination image formed by the 2002 World Cup. Annals of Tourism Research, 32, 839-858. DOI: 10.1016/j.annals.2004.11.006.

[38] LI, X., C.-K. CHENG, H. KIM and J. F. PETRICK, 2008. A systematic comparison of first-time and repeat visitors via a two-phase online survey. Tourism Management, 29(2), 278-293. DOI: 10.1016/j.tourman.2007.03.010.

[39] LIU, Y., M. HULTMAN, A. B. EISINGERICH and X. WEI, 2020. How does brand loyalty interact with tourism destination? Exploring the effect of brand loyalty on place attachment. Annals of Tourism Research, 81, 102879. DOI: 10.1016/j.annals.2020.102879.

[40] LOPES, S. D. F., 2011,. Destination image: Origins, developments and implications. Revista de Turismo y Patrimonio Cultural, 9(2), 305-315. DOI: 10.25145/j.pasos.2011.09.027.

[41] MCDOWALL, S., 2010. International tourist satisfaction and destination loyalty: Bangkok, Thailand. Asia Pacific Journal of Tourism Research, 15(1), 21-42.

[42] MECHINDA, P., S. SERIRAT and N. GULID, 2009. An examination of tourists' attitudinal and behavioral loyalty: Comparison between domestic and international tourists. Journal of Vacation Marketing, 15(2), 129-148. DOI: 10.1177/1356766708100820.

[43] MESSUKESKUS, 2018. Press release | Tourism Survey 2018: Finns travel to break away from their busy everyday lives - responsibly. [online] Available at: https://messukeskus.com/press-release/tourism-survey-2018-finns-travel-break-awaybusy-everyday-lives-responsibly/?lang=en [12 May 2019].

[44] MOHAMMED, B. B., N. I. HAIRUL, M. DALIL and A. KAWU, 2014. Moderating role of affective destination image on the relationship between tourists satisfaction and 
behavioural intention: evidence from Obudu Mountain Resort. Journal of Environment and Earth Science, 4(4), 47-60.

[45] MOLINA, A., M. GOMEZ, G. MAR and D. MARTÍN-CONSUEGRA, 2010. Tourism marketing information and destination image management. African Journal of Business Management, 4(5), 722-728.

[46] NUNKOO, R., 2013. Relationship between Destination Image and Loyalty: Developing Cooperative Branding for Rural Destinations. ISSN 16941225.

[47] OPPERMANN, M., 2000. Tourism destination loyalty. Journal of travel research, 39(1), 78-84. DOI: $10.1177 / 004728750003900110$.

[48] PANTOUVAKIS, A., 2013. The moderating role of nationality on the satisfaction loyalty link: evidence from the tourism industry. Total Quality Management \& Business Excellence. 24(9/10):1174-1187. DOI:10.1080/14783363.2013.776758

[49] PETRICK, J., D. MORAIS and W. NORMAN, 2001. An examination of determinants of entertainment vacationer's intention to revisit. Journal of Travel Research, 40(1), 41-48. DOI: $10.1177 / 004728750104000106$.

[50] PRAGUE CITY TOURISM. Prague walks [online]. 2021 [cit. 2021-01-12]. Available at: https://www.prague.eu/en/walks

[51] PRAYAG, G., 2007. Exploring the relationship between destination image and brand personality of a tourist destination: an application of projective techniques. Journal of Travel and Tourism Research, Fall, 111-130.

[52] PRAYAG, G., 2008. Image, satisfaction and loyalty-The case of Cape Town. Anatolia, 19(2), 205-224. DOI: 10.1080/13032917.2008.9687069.

[53] PRAYAG, G. and C. RYAN, 2011. Antecedents of tourists' loyalty to Mauritius: The role and influence of destination image, place attachment, personal involvement, and satisfaction. Journal of Travel Research, 51(3), 342-356. DOI:10.1177/0047287511410321

[54] RAGB, H., A. A. MAHROUS and A. GHONEIM, 2020. A proposed measurement scale for mixed-images destinations and its interrelationships with destination loyalty and travel experience. Tourism Management Perspectives, 35, 100677. DOI: 10.1016/j.tmp.2020.100677.

[55] ROWLEY, J., 2005. The four Cs of customer loyalty. Marketing intelligence \& planning. DOI: 10.1108/02634500510624138.

[56] RYGLOVÁ, K., I. RAŠOVSKÁ, J. ŠÁCHA and V. MARÁKOVÁ, 2018. Building Customer Loyalty in Rural Destinations as a Pre-Condition of Sustainable Competitiveness. Sustainability, 10 (4): 957. DOI: 10.3390/su10040957.

[57] SCHNEIDER, B. and S. S. WHITE, 2004. Service quality: Research perspectives. Thousand Oaks, CA: Sage Publications. ISBN: 0761921478.

[58] SHESKIN, D. J., 2011. Handbook of Parametric and Nonparametric Statistical Procedures, Fifth Edition. Chapman and Hall/CRC. ISBN 9781439858011.

[59] SKOGLAND, I. and J. A. SIGUAW, 2004. Are your satisfied customers loyal?. Cornell hotel and restaurant administration quarterly, 45(3), 221-234. DOI: $10.1177 / 0010880404265231$. 
[60] SOM, A. P. M., S. F. M. SHIRAZI, A. MARZUKI and J. JUSOH, 2011. A critical analysis of tourist satisfaction and destination loyalty. Journal of Global Management, 2(1), 178183.

[61] ŠTUMPF, P., V. VOJTKO and P. JANEČEK, 2020. Do European tourists intend to revisit the same countries? Effect of satisfaction in European Union destinations. Scandinavian Journal of Hospitality and Tourism, 20(4), 398-417. DOI: 10.1080/15022250.2020.1807405.

[62] SUN, X., C. G. Q. CHI and H. XU, 2013. Developing destination loyalty: The case of Hainan Island. Annals of tourism research, 43, 547-577.

[63] SWARBROOKE, J. and S. HORNER, 2007. Consumer behavior in tourism. ButterworthHeinemann: Oxford. ISBN: 978-0-7506-6735-7

[64] TASCI, A. D. A. and W. C. GARTNER, 2007. Destination Image and its Functional Relationships, Journal of Travel Research, 45(4): 413-425. DOI: $10.1177 / 0047287507299569$.

[65] THE GUARDIAN, 2019. The fall of Prague: 'Drunk tourists are acting like they've conquered our city' [online]. [cit. 2021-01-12]. Available at: https://www.theguardian.com/world/2019/aug/25/prague-drunk-tourists-conquer-our-city

[66] THE MINISTRY OF EDUCATION, YOUTH AND SPORTS, 2020. Data o studentech, poprvé zapsaných a absolventech vysokých škol (Data on students, first-time enrolled and university graduates) [online]. [cit. 2021-01-11]. Available at: https://www.msmt.cz/vzdelavani/skolstvi-v-cr/statistika-skolstvi/data-o-studentechpoprve-zapsanych-a-absolventech-vysokych?lang=1

[67] TIAN-COLE, S. and J. CROMPTION, 2003. A conceptualization of the relationships between service quality and visitor satisfaction, and their links to destination selection. Leisure studies, 22(1), 65-80.

[68] UNWTO, 2020. International tourism down 70\% as travel restrictions impact all regions [online]. [cit. 2021-01-06]. Available at: https://www.unwto.org/news/internationaltourism-down-70-as-travel-restrictions-impact-all-regions.

[69] USAKLI, A. and S. BALOGLU, 2011. Brand personality of tourist destinations: an application of self-congruity theory. Tourism Management, 32, 114-137. DOI: 10.1016/j.tourman.2010.06.006.

[70] VISIONOFHUMANITY.ORG, 2020. Global Peace Index: Czech Republic [online]. [cit. 2020-08-06]. Available at: http://visionofhumanity.org/indexes/global-peace-index/

[71] WANG, C. Y. and M. K. HSU, 2010. The relationships of destination image, satisfaction, and behavioral intentions: An integrated model. Journal of Travel \& Tourism Marketing, 27(8), 829-843. DOI:10.1080/10548408.2010.527249.

[72] WU, C. W., 2016. Destination loyalty modeling of the global tourism. Journal of Business Research, 69(6), 2213-2219. DOI: 10.1016/j.jbusres.2015.12.032.

[73] XIANG, Z. and U. GRETZEL, 2010. Role of social media in online travel information search. Tourism Management, 31, 179-188.

[74] YOON, Y. and M. UYSAL, 2005. An examination of the effects of motivation and satisfaction on destination loyalty: A structural model. Tourism Management, 26(1), 4556. DOI: 10.1016/j.tourman.2003.08.016. 
[75] YUKSEL, A., F. YUKSEL and Y. BILIM, 2010. Destination attachment: effects on customer satisfaction and cognitive, affective and conative loyalty. Tourism Management, 31, 274-284. DOI: 10.1016/j.tourman.2009.03.007.

[76] ZEITHAML, V. A. and M. J. BITNER, 2003, Service Marketing: Integrating Customer Focus across the Firm, New York: McGraw-Hill. ISBN: 0078112109.

[77] ZHANG, H., X. FU, L. A. CAI and L. LU, 2014. Destination image and tourist loyalty: A meta-analysis. Tourism Management. 40, 213-223. DOI: 10.1016/j.tourman.2013.06.006. 